\title{
THE EARLY HISTORY OF GLACIAL THEORY IN BRITISH GEOLOGY
}

\author{
By Bert Hansen \\ (Program in the History of Science, Princeton University, Princeton, New Jersey o8540, \\ U.S.A.)
}

\begin{abstract}
Much of the history of British geological thought in the second quarter of the nineteenth century centered on problems which are now explained by reference to the events of the Ice Age. This paper reviews the data and theories then current among British geologists as the background of the British response to Louis Agassiz's "modern" theory of a glacial epoch. Today, as we read Agassiz's amazing speculation, our own sympathy for the striking accuracy of his ideas masks from us the difficulty they faced in gaining acceptance. By first examining the context into which the glacial theory was introduced, we can then appreciate the novelty of Agassiz's efforts and understand the long delay in their achieving prominence. The present examination suggests that this delay was due to the unfortunate merger of Agassiz's new ideas with the older drift theory of Charles Lyell.
\end{abstract}

RÉsumé. L'histoire ancienne de la théorie glaciaire en géologie britannique. Une grande partie de l'histoire de la géologie britannique élaborée dans le second quart du igème siècle était centrée sur des problèmes qui sont actuellement expliqués par référence aux évènements de l'âge glaciaire. Ce rapport passe en revue les données et les théories alors courantes parmi les géologues britanniques comme arrière plan de la réponse anglaise à la théorie moderne de l'âge glaciaire de Louis Agassiz. Aujourd'hui lorsque nous lisons l'étonnante spéculation d'Agassiz, notre propre sympathie pour l'exactitude de ses idées nous masque la difficulté qu'elles affrontent pour obtenir leur acceptation. En commençant par examiner le contexte dans lequel la théorie glaciaire fut introduite, nous pouvons apprécier le long délai qu'elle mit à s'imposer. L'examen présent suggère que ce délai était dû à la mauvaise fusion des idées nouvelles d'Agassiz et de l'ancienne théorie du mouvement de Charles Lyell.

Zusammenfassung. Die frühe Geschichte der Eiszeittheorie in der britischen Geologie. Historisch gesehen, waren viele Überlegungen der britischen Geologie im zweiten Viertel des 19. Jahrhunderts auf Probleme gerichtet, die heute im Zusammenhang mit den Ereignissen der Eiszeit erklärt werden. Dieser Aufsatz beleuchtet die seinerzeit bei den britischen Geologen verbreiteten Kenntnisse und Theorien als Hintergrund der britischen Reaktion auf Louis Agassiz's "moderne" Theorie einer Eiszeit. Wenn wir heute die erstaunlichen Spekulationen Agassiz's lesen, übersehen wir in unserer Bewunderung für die Treffsicherheit seiner Ideen die Schwierigkeiten, die sich ihrer Anerkennung entgegenstellten. Prüft man zuerst die Situation, welche die Eiszeittheorie bei ihrer Einführung vorfand, so kann man die Neuheit von Agassiz's Ansätzen würdigen und die lange Verzögerung verstehen, mit der sie Beachtung fanden. Die vorliegende Überprüfung legt nahe, dass diese Verzögerung auf die unglückliche Verknüpfung von Agassiz's neuen Ideen mit der älteren Drifttheorie von Charles Lyell zurückzuführen ist.

AT the beginning of the nineteenth century few geologists anywhere in Europe regarded glaciers, or land ice in general, as anything more than a phenomenon peculiar to high altitudes and high latitudes with no role in geological processes. By the end of the century most regarded glaciers as a powerful agent in the production of modern landforms and in the formation of widely occurring superficial deposits. In Britain, the second quarter of the nineteenth century saw the first discussions of Louis Agassiz's glacial theory, a temporary prominence, and then a nearly complete rejection of glacial ideas with their submergence in an iceberg theory. North (1943, p. 24) sketched some of this history but seemed to attribute the British repudiation of glacial ideas to prejudice without explaining how or why this occurred. Bremner's (1935, p. 26I) quick survey of glacial geology in Scotland corroborated the fact but likewise attempted no explanation of it. And despite a recent renewed interest in the history of "diluvial" and "glacial" theories (see for example, the writings of Lurie (r96o), Bailey (1962), Seylaz (1962), Chorley and others (1964), Davies (1968), Carozzi (Agassiz, 1967) and Page (unpublished)), no attention has been directed to this particular problem.

Large areas of English and Scottish bedrock are covered with irregular accumulations of gravel, sands, clays, large boulders and boulder clay. The strictly superficial character of such deposits seems to indicate recent origins, and the extremely jumbled and unstratified nature of 
the accumulations suggests rapid deposition. In the early nineteenth century such characteristics had not been observed in any of the older consolidated rocks. (Much later, A. C. Ramsay was to recognize such characteristics in Permian breccias and argue for Permian glaciation.) William Buckland called attention to these deposits in his inaugural lecture when he was appointed Professor of Mineralogy and Geology at Oxford in 1820. He expanded his explanation in papers in the Philosophical Transactions (1822) and in the Transactions of the Geological Society, but his views were more widely circulated in his Reliquiae diluvianae (1823; 2nd edition, 1824). He argued that recent deposits could be distinguished as either diluvial or alluvial - the former resulting from a general and recent inundation of the Earth and the latter due to presently acting agents, for example deposition at the mouths of rivers or at the base of eroding cliffs (Buckland, I824, p. 2, I85-90, et passim). For Buckland, as for most geologists at this time, the evidence of a violent convulsion of water was patent in all the diluvial deposits. One had only to look to be convinced. Buckland offered over 200 quarto pages describing the deposits and concluded (p. 199):

"... we have evidence, that a current from the north has drifted to their present place, along the whole east coast of England, that portion of the pebbles there occurring, which cannot have been derived from this country; a certain number of them may possibly have come from the coast of Scotland, but the greater part have apparently been drifted from the other side of the German ocean."

In addition to the evidence from unstratified deposits of distantly derived fragments, certain valleys and other landforms were attributed to diluvial erosion. Reports by Colonel Imrie and Sir James Hall furnished Buckland (1824, p. 202) much evidence of valleys apparently scoured out "by the attrition of heavy bodies, set in motion by a great force of water in rapid movement". Both of those authors noted particularly the linear scratches and furrows on exposed parts of bedrock and had no doubt that these grooves were cut by the huge erratic blocks found in the vicinity. Buckland's opportunity to associate this deluge with the "Noachian Flood" was certainly not accidental, but should not be over-emphasized. The physiographical material presented by Buckland has been regarded quite sympathetically by modern physical geographers (Chorley and others, I964, p. 99-100).

Buckland's splendid work encouraged other geologists to examine the superficial deposits throughout the British Isles. In many of the studies of the I820's and 1830's the diluvial concept was evident, but some important geologists found difficulties with Buckland's concept and modified their views accordingly-regarding marine currents rather than a terrestrial deluge as the origin of diluvium and no longer restricting the period of deposition to a single event of short duration. Nevertheless, the central point of aqueous non-fluvial deposition was unchanged. The adherents of this new marine theory, notably Adam Sedgwick, Roderick Murchison, and others, called attention to the recent discoveries of marine shells in superficial beds, even at hundreds of feet above sea-level.

At this time also, many observations of changes of sea-level relative to land were being made. Charles Lyell and Charles Darwin each presented many papers reporting evidence of sea-level changes and both agreed on the probability of land movement to account for the relative change of level. The idea of marine deposition of drift was certainly supported by the popularity of ideas of recent emergence of the land. In February i834, George Bellas Greenough, then President, reminded the Geological Society of London that "among the subjects which for some years past engaged the thoughts of geologists, none perhaps has excited so general and intense an interest as the Theory of Elevation" (Greenough, I834, p. 54).

Yet there were many difficulties in explaining diluvium or drift* as a marine deposit, including its general lack of stratification, the angular character of many of the rock fragments

\footnotetext{
* The terms diluvium, drift, erratic phenomena, and later glacial phenomena were used interchangeably by the British geologists of this period. The first three, and sometimes even the fourth, were used strictly as descriptive terms with no genetic significance. Drift theory, however, for some reason referred to Lyell's explanation by means of
icebergs.
} 
and the occurrence of huge "erratic" blocks of rock. In time these anomalies might have weakened the theory considerably but two circumstances prevented this. At first these problems were not clearly recognized, and to the extent to which they were, they could be resolved by assuming the agency of ocean currents due to rising mountains, earthquakes, volcanoes and other paroxysmal events. Since relatively little was known about the ocean bottom, such hypotheses raised little opposition. The more important development was Lyell's introduction of floating ice into the theory of marine deposition. This single modification, I argue, prevented the rapid acceptance of Agassiz's glacial theory and delayed for decades its achieving dominance.

Lyell argued for the role of floating ice in boulder transport in the first edition of his Principles (vol. 3, May i833). On i9 February i836, he reviewed and strengthened this idea in his Presidential Address to the Geological Society (Lyell, I836, p. 382-83). Two weeks earlier Murchison (1836, p. 335) had discussed the drift deposits and had acknowledged that icebergs might be the verae causae of erratic blocks. The fifth edition of the Principles offered a section entitled "Effects of ice in removing stone" (Lyell, I837, vol. I, p. 173-74). In this passage Lyell explained first that rocks are more easily moved when ice adheres to them because of the lower density of the whole mass. Then he noted the amount of debris carried by glaciers and the moraines formed of this debris at the extremes of a glacier's movement. But he devoted most attention to the breaking off of ice islands where glaciers descend to a shore and to the transport of rocks by such icebergs. Floating ice was even part of Lyell's explanation of the transport of erratic blocks from the Alps to the Jura. Earthquakes, avalanches, spring thaws, the bursting of temporary natural dams and glaciers were also involved in his explanation (Lyell, I837, vol. I, p. 299-300) for which glaciers alone would have been sufficient, as Agassiz would later show.

Hypotheses of iceberg transport of drift were also buttressed by the current interest in reports on northern and Antarctic icebergs. Typical of this interest was a paper from Canada by Bayfield ( 1836$)$; the report was communicated to the Geological Society by Lyell himself. Many similar reports were published during this period, including the observations of Darwin, naturalist on Beagle, and of Captain J. C. Ross, discoverer of Victoria Land.

Lyell's modification strengthened the marine theory. Now, more variation and irregularity in deposition could be accounted for without invoking strange ocean-bottom currents and sudden land movements. Because fragments transported by ice do not suffer the attrition of water-carried pieces, angular and subangular rocks could be accounted for. Advocates of uniformity were encouraged by the existence of modern icebergs loaded with detritus. Even the idea of icebergs at Britain's latitude seemingly did not raise problems (Lyell, I836, p. $3^{82}$; Murchison, 1836, p. 335).

Having been encouraged to study glaciers by his friend Jean de Charpentier, Louis Agassiz first presented his theory of glaciation to the Société Helvétique des Sciences Naturelles at Neuchâtel in 1837 . He demonstrated the glacial character of a wide range of phenomena, while rejecting any agent except land ice for the polishing of rocks and also denying currents a role in the transport of boulders and morainal deposits. He postulated a world-wide fall of temperature as the cause of the glacial epoch and pointed out modern glaciers as the surviving remnants of a general ice sheet. In less than a year this speech was published in English in the Edinburgh New Philosophical Fournal (Agassiz, 1838). Within the next 6 years these ideas first rose to wide recognition and then fell quickly to a quite uninfluential position. Only decades later were they slowly revived.

The first important convert to Agassiz's glacial theory was the Reverend William Buckland, who visited the Swiss naturalist in October 1838 . The glacial phenomena in the Jura did not convince Buckland until he examined actual glaciers in the Alps as well. He then described to Agassiz the glacial traces in Scotland which he had included in his Reliquiae diluvianae in 
1823. Upon his return to England, Buckland helped spread glacial ideas and on 5 October I840 wrote to Agassiz of a particular triumph. "Lyell has adopted your theory in toto!!! On my showing him a beautiful cluster of moraines within two miles of his father's house, he instantly accepted it, as solving a host of difficulties that have all his life embarrassed him." (Agassiz, I 885, vol. I, p. 309). I 840 also saw the appearance of Agassiz's extensive exposition of the theory in Études sur les glaciers and a paper summarizing the Études before the Glasgow meeting of the British Association for the Advancement of Science. Darwin met Agassiz for the first time at this meeting and in the following March wrote to him, "I have enjoyed reading your work on glaciers, which has filled me with admiration" (Lurie, I96o, p. I0o). Darwin also accepted Agassiz's glacial explanation of the parallel roads of Glen Roy in Scotland, completely rejecting the marine explanation which he himself had published years before (Lurie, I96o, p. IOI). Nonetheless we shall see that these three leading geologists were not fully converted to the glacial theory. Buckland may have been, but Lyell and Darwin seem only to have modified their views within the older iceberg-marine theory.

Three papers by Agassiz, Buckland and Lyell before the Geological Society of London in the winter of $1840-4 \mathrm{I}$ focused British attention on glacial ideas, but thereafter interest dropped and the glacial concept as a particular way of seeing a wide range of phenomena lost its independent existence. On 4 November 1840 , Agassiz read the first of these important papers. He began by recalling others who had observed glaciers, particularly Venetz and Charpentier, who ascribed the transport of erratic boulders in Switzerland to the agency of glaciers. He rejected their view that a formerly greater altitude of the Alps caused glaciers to push the blocks to their present positions, because erratics were found in Europe, Asia and America. Rather he assumed the former existence of a general ice sheet which was gradually reduced to the local glaciers presently found at high altitudes. Agassiz then considered another general view of the same phenomena. As the Proceedings reported:

"To avoid useless discussion, he states, that in attributing to the action of glaciers a considerable portion of the results hitherto ascribed exclusively to that of water, he does not wish to maintain that everything hitherto assigned to the agency of water has been produced by glaciers; he only wishes that a distinction be made in each locality between the effects of the different agents; and he adds, that long-continued practice has taught him to distinguish easily, in most cases, the effects produced by ice from those produced by water" (Agassiz, 1840 , p. 328$)$.

Following this, Agassiz described in detail the various phenomena found in conjunction with existing glaciers and compared these with phenomena in the British Isles.

". . . the author argues, that great sheets of ice, resembling those now existing in Greenland, once covered all the countries in which unstratified gravel is found; that the angular blocks found on the surface of the rounded materials were left in their present position at the melting of the ice; and that the disappearance of great bodies of ice produced enormous debacles and considerable currents, by which masses of ice were set afloat, and conveyed, in diverging directions, the blocks with which they were charged" (Agassiz, 1840, p. 331).

Although he acknowledged the likelihood of floating ice, he assigned no particular phenomena to its action, and the currents to which he referred were from glacial melt water on land not ocean bottom.

Agassiz's paper was immediately followed by "A memoir on the evidence of glaciers in Scotland and the north of England" by Buckland, then President of the Geological Society. Most of this memoir consisted of careful description of moraines and other glacial effects, many of which were widely known, though generally attributed to other agents. Buckland (1840, p. 335) also related that in the district near Comrie he "tested the value of the glacial theory by marking in anticipation on a map the localities where there ought to be evidence of glaciers having existed, if the theory were founded on correct principles. The results coincided with the anticipations." Still more descriptions were given and a crucial piece of evidence was explained with great facility:

"Some [striae, grooves and polished surfaces] may be imagined to have been produced by stones projecting from the side or bottom of floating masses of ice: but it is impossible, Dr. Buckland observes, to account by such agency for the polish and striae on rocks at Blackford Hill, two miles south of Edinburgh. ... On the 
south face of this hill, at the base of a nearly vertical cliff of trap, is a natural vault, partly filled with gravel and sand. ... The sides and roof of the vault are highly polished, and covered with striae, irregularly arranged with respect to the whole surface, but in parallel groups over limited extents. These striae, Dr. Buckland says cannot be referred to the action of pebbles moved by water; ist, because fragments of stone set in motion by a fluid cannot produce such continuous parallel lines; and 2ndly, because if they could produce them, the lines would be parallel to the direction of the current: it is impossible he adds, to refer them to the effects of stones fixed in floating ice, as no such masses could have come in contact with the roof of a low vault. On the contrary, it is easy, he says, to explain the phenomena of the polish by the long-continued action of fragments of ice forced into the cave laterally from the bottom of a glacier descending the valley, on the margin of which the vault is placed; and the irregular grouping of the parallel striae [by] the unequal motion of different fragments of ice, charged with particles of stone firmly fixed in them, like the teeth of a file" (Buckland, 1840, p. 336-37).

The third important memoir of 1840 was read by Lyell to the Geological Society in November and December. At the outset he explained his interest in this district:

"Three classes of phaenomena connected with the transported superficial detritus of Forfarshire, Mr. Lyell had referred, for several years, to the action of drifting ice. . . . When, however, he attempted to apply the theory of drifting ice over a submerged country to facts with which he had been long acquainted in Forfarshire, he found great difficulty. ...

Since, however, Professor Agassiz's extension to Scotland of the glacial theory, and its attendant phaenomena, Mr. Lyell has re-examined a considerable portion of Forfarshire, and having been convinced that glaciers existed for a long time in the Grampians, and extended into the low country, many of his previous difficulties have been removed" (Lyell, i840, p. 337-38).

Then Lyell proceeded to describe the phenomena of the district in great detail and with remarkably little theory (either glacial or drift). His paper presented the glacial concept much less clearly and more tentatively than the straightforward and sometimes eloquent memoirs of Agassiz and Buckland. Nonetheless, the three men together focused attention on glacial theory and gave the British geological community an opportunity to react to it.

Adverse reaction was immediately strong and ultimately overwhelming. The glacial theory was not disproved but it was argued out of importance. The discussion was opened by one of the most firm proponents of the drift theory:

\footnotetext{
"Mr. Murchison called upon the mathematicians and physical geographers to speak of the objections to Dr. Buckland's glacial hypothesis, he himself should attend only to the facts of the case. Of the scratches and polish on the surface of certain rocks there is no doubt, and 'Are glaciers the cause?' is the question. Could they be done by ice alone? If we apply it to any as the necessary cause, the day will come when we shall apply it to all. . . Dr. Buckland has in his paper assumed that all these heaps of diluvium are moraines; but I would rather examine the subject under the old name Diluvium, and with our old ideas of diluvial action, than by using the term moraines, assume the question proved" (Woodward, 1908, p. 138).
}

After further discussion with comments by Agassiz, Lyell and Whewell:

\begin{abstract}
"[Buckland] argued the à priori credit to be attached to his 'narrative', from the circumstance of his having been a 'sturdy' opponent of Professor Agassiz when he first broached the glacial theory, and having set out from Neuchatel with the determination of confounding and ridiculing the professor. But he went out and saw all these things, and returned concerted. ... He referred to Professor Agassiz's book, and condemned the tone in which Mr. Murchison had spoken of the 'beautiful' terms employed by the professor to designate the glacial phenomena" (Woodward, I908, p. I41; italics added).
\end{abstract}

Within the general context of British geological thought at this time, Murchison's (I839) huge monograph on The Silurian system was highly regarded and widely known. In several chapters in the first volume, Murchison reviewed the explanations of erratic blocks. His conclusions were indicative of the most widely held views. Because the marine origin of the deposits was assumed, the range of possible agents of transport did not include glaciers. Ocean currents and fluvial means were excluded for various reasons and icebergs remained the most likely agent. Murchison ( 1839 , vol. I, p. 542) specifically called attention to the recent observations of icebergs furnished by Darwin's voyage on Beagle.

Further indications of the general attitude toward these questions are found in the annual addresses by the Presidents of the Geological Society which reviewed the geological activity and accomplishment of the previous year. Because of their wide distribution, these addresses 
served not only to describe but also in some way to define the general British view on geological matters. The addresses of $I_{84}{ }^{-4} 43$ clearly recorded the decline of the glacial theory. In I84I, Buckland ( $\mathrm{I} 84 \mathrm{I}$, p. $5 \mathrm{I} 6$ ) devoted 8 pages (in the Proceedings) to "Glacial theory" and concluded by trying to compromise the divergent opinions. He suggested that both floating ice and glaciers shared responsibility for drift and erratic blocks, and predicted that "the glacialist will probably abandon his universal covering of ice and snow, and be content with glaciers on the elevated regions of more southern latitudes than now allow of their formation."

The compromise was furthered by Murchison, President of the Geological Society for the next 2 years. His open opposition was a powerful weapon for destroying Agassiz's achievement through compromise. Seventeen pages of the published transcript of Murchison's first address were devoted to the glacial theory. He reviewed various opinions antagonistic to Agassiz's views and then discussed some of the evidence, most of which he saw as indicative of marine deposition. But his principal complaint was that Agassiz went too far.

"In fact, the 'glacier' theory, as extended by its author in proving too much, may be said to destroy itself. Let it
be limited to such effects as are fairly deducible from the Alpine phaenomena so clearly described by Agassiz,
and we must all admire in it a vera causa of exceeding interest; but once pass the bounds of legitimate induc-
tion from that vera causa, and try to force the many and highly diversified superficial phaenomena of the
surface of the globe, into direct agreement with the evidence of the action of ice under the atmosphere, and
you will be driven forward, like the ingenious author of the theory, so to apply it to vast traces of the globe,
as in the end to conduct you to the belief, that not only both Northern and Southern hemispheres, but even
quasi tropical regions, were shut up a long period in an icy mantle" (Murchison, 1842, p. 677).

Murchison's confidence in his own views of marine deposition prevented him from seeing that it was precisely in the inference of formerly widespread glaciers from "many and highly diversified superficial phaenomena", even in quasi-tropical regions, that Agassiz's theory was to be vindicated as a scientific success. Later in this address Murchison, in his typical patronizing manner, noted a change in Buckland's views:

"I cannot but heartily congratulate the Society on the results at which he has now arrived. I rejoice in the prudence of my friend, who has not permitted the arguments of the able advocate [Agassiz] to appear as the sober judgment of so distinguished a President of the Geological Society. In fact, it is now plain that Dr. Buckland abandons, to a great extent, the theory of Agassiz, and admits fully the effects of water as well as of ice, to account for many of the long-disputed phaenomena" (Murchison, 1842, p. 685).

Unfortunately, the eloquence and influence of Murchison delimited the general outlook of British geology for at least two decades. In his Presidential Address of the following year, Murchison (1843, p. 93-94) re-affirmed the general drift theory and clarified his acceptance of local or Alpine glaciation while utterly rejecting the continental glaciation which was such a key part of Agassiz's view.

Ideas of terrestrial ice were not forgotten but they were merged into part of a somewhat expanded drift theory. Thus a general sheet of ice was no longer considered, although particular local effects were attributed to glaciers. The generality and flexibility, even ambiguity, of such a view provided considerable adaptability. The strength of this drift theory lay partly in the fact that the nature of deposition from floating ice or the ploughing up of the ocean beds, or the sculpturing of underwater landforms could not be directly observed. With a whole range of agents, including glaciers, icebergs, terrestrial melt water, ocean currents and various combinations of these available, it was not too difficult to "explain" all the phenomena. Different geologists emphasized various proportions and combinations of water and ice. Although floating ice coupled with marine deposition complicated a few of the explanations (such as erratic blocks in the Jura), the uncertainty and variability of this device provided an adaptability which more than compensated for these few cases. By contrast, Agassiz's view which subsumed such diverse and widespread phenomena under a single cause appeared rigid and even dogmatic.

With the general acceptance of this compromise theory in the early I840's the rapid succession of changing views - from diluvial theory to drift theory to glacial theory and then 
back to a slightly expanded drift theory - came to an end. The main features of Agassiz's theory were thus lost to the scientific community for a time. Only after further development of observations and theory did the glacial ideas of Louis Agassiz re-emerge from the modified drift theory. In the I840's and I850's floating ice was given prominence over land ice, but finally by the I870's and I880's glaciers had regained clear ascendancy.

MS. received 28 October 1968 and in revised form 4 September 1969

\section{REFERENGES}

Agassiz, E. C., ed. 1885. Louis Agassiz, his life and correspondence. Boston, Houghton, Mifflin and Co. 2 vols.

Agassiz, L. 1838 . Upon glaciers, moraines, and erratic blocks; being the address delivered at the opening of the Helvetic Natural History Society, at Neuchatel, on the 24 th of July 1837 , by its President. Edinburgh New Philosophical Journal, Vol. 24 , p. $364-83$.

Agassiz, L. 1840. On glaciers, and the evidence of their having once existed in Scotland, Ireland, and England. Proceedings of the Geological Society of London, Vol. 3, Pt. 2, No. 72, p. 327-32.

Agassiz, L. 1967. Studies on glaciers, preceded by the 'Discourse of Neuchatel'. Translated and edited by A. V. Carozzi. New York, Hafner.

Bailey, E. 1962. Charles Lyell. London, etc., Thomas Nelson and Sons Ltd. (British Men of Science.)

Bayfield, H. W. 1836 . A notice on the transportation of rocks by ice, extracted from a letter to Charles Lyell. Proceedings of the Geological Society of London, Vol. 2, No. 43, p. 223.

Bremner, A. 1935. Glacial and post-glacial geology. (History of the Edinburgh Geological Society 1835-1934.) Transactions of the Edinburgh Geological Society, Vol. 13, Pt. 2, p. 26o-70.

Buckland, W. 1824. Reliquiae diluvianae. London, John Murray.

Buckland, W. 1840. On the evidences of glaciers in Scotland and the north of England. Proceedings of the Geological Society of London, Vol. 3, Pt. 2, p. No. 72, 332-37, 345-48.

Buckland, W. 184i. Anniversary address of the President, February 19. Proceedings of the Geological Society of London, Vol. 3 , Pt. 2, No. 8I, p. 469-540.

Chorley, R. J., and others. 1964 . The history of the study of landforms or the development of geomorphology, by R. F. Chorley, A. F. Dunn and R. P. Beckinsale. Vol. $x$. London, Methuen and Co. Ltd.

Davies, G. L. I968. Early discoverers. XXVI. Another forgotten pioneer of the glacial theory: James Hutton (1 726-97). Fournal of Glaciology, Vol. 7, No. 49, p. I $15^{-16 .}$

Greenough, G. B. 1834 . Anniversary address of the President, February 21. Proceedings of the Geological Society of London, Vol. 2, No. 35, p. 42-70.

Lurie, E. I96o. Louis Agassiz: a life in science. Chicago, University of Chicago Press.

Lyell, C. 1836 . Anniversary address of the President, February 19. Proceedings of the Geological Society of London, Vol. 2, No. 44, p. 357-90.

Lyell, C. 1837 . The principles of geology. Philadelphia, James Kay. [First American edition from the fifth London edition.]

Lyell, C. 1840. On the geological evidence of the former existence of glaciers in Forfarshire. Proceedings of the Geological Society of London, Vol. 3, Pt. 2, No. 72, p. 337-45.

Murchison, R. I. 1836 . The gravel and alluvia of S. Wales and Siluria, as distinguished from a northern drift covering Lancashire, Cheshire, N. Salop, and parts of Worcester and Gloucester. Proceedings of the Geological Society of London, Vol. 2, No. 43, p. 230-336.

Murchison, R. I. 1839 . The Silurian system. London, John Murray.

Murchison, R. I. 1842. Anniversary address of the President, February 18. Proceedings of the Geological Society of London, Vol. 3, Pt. 2, No. 86, p. $637-87$.

Murchison, R. I. 1843. Anniversary address of the President, February 17. Proceedings of the Geological Society of London, Vol. 4, Pt. I, No. 93, p. $65^{-1} 5^{1}$.

North, F.J. I943. Centenary of the glacial theory. Proceedings of the Geologists' Association, Vol. 54, Pt. I, p. I-28.

Page, L. E. Unpublished. The rise of the diluvial theory in British geological thought. [Ph.D. thesis, University of Oklahoma, 1963.$]$

Seylaz, L. I962. Early discoverers. XV. A forgotten pioneer of the glacial theory: John Playfair (1748-1819). Journal of Glaciology, Vol. 4, No. 31, p. 1 24-26.

Woodward, H. B. I908. The history of the Geological Society of London, .... Longmans, Green and Co. [This work prints the notes taken at the meetings by S. P. Woodward.] 